\title{
PENGARUH BERKUMUR EKSTRAK BUAH DELIMA TERHADAP TERAPI GINGIVITIS
}

\author{
(GARGLING EFFECT OF POMEGRANATE EXTRACT MOUTHWASH \\ IN GINGIVITIS THERAPY)
}

\author{
Indra Mustika Setia Pribadi, Nunung Rusminah, Ira Komara \\ Departemen Periodontia \\ Fakultas Kedokteran Gigi, Universitas Padjadjaran \\ Jl. Sekeloa Selatan No.1 Bandung \\ E-mail: indra.mustika@fkg.unpad.ac.id
}

\begin{abstract}
Pomegranate is one kind of fruit that is rich in antioxidants. The flavonoid ingredient in pomegranate can prevent gingivitis. The purpose of this study was to compare the effects of pomegranate extract 5 and $10 \%$ as a mouthwash to reduce gingival score. This study was quasi experimental which performed with single blind and pre and post study design. The materials we used were pomegranate extract which is formed as a mouthwash at concentration of 5\% and $10 \%$. Purposive sampling technique was used to select 30 subjects. The research subjects divided into 2 groups: group A gargling with pomegranate extract 5\% and group B gargling with the $10 \%$. Subjects were asked gargled for 15 days twice daily and the results will be evaluated using Loe and Silness gingival index. The results showed that application of pomegranate extract at concentration $10 \%$ can reduced the gingival index better, i.e $48 \%$ in the $1^{\text {st }}$ week and $77 \%$ at $2^{\text {nd }}$ week compared to a decrease in gingival index by pomegranate extract concentration of $5 \%$, i.e $11 \%$ in the $1^{\text {st }}$ week and $27 \%$ at $2^{\text {nd }}$ week. In conclusion, increasing concentration of the pomegranate extract in mouthwash can reduce the severity of gingivitis more effectively.
\end{abstract}

Key words: mouthwash, pomegranate extract, gingivitis

\begin{abstract}
Abstrak
Delima merupakan salah satu buah yang kaya antioksidan. Kandungan flavonoid dalam delima berkhasiat dapat mencegah gingivitis. Penelitian ini bertujuan untuk mengetahui perbandingan efek ekstrak buah delima yang dibuat dalam bentuk obat kumur dengan konsentrasi 5 dan $10 \%$ sebagai obat kumur terhadap penurunan skor gingiva. Penelitian ini dilakukan dengan metode eksperimental semu menggunakan desain single blind, pre and post study. Sampel sebanyak 30 orang diambil secara purposive sampling. Subyek penelitian dibagi menjadi 2 kelompok, yaitu kelompok A berkumur dengan ekstrak buah delima 5\% dan kelompok B berkumur dengan ekstrak buah delima $10 \%$. Subyek diminta berkumur 2 kali sehari selama 15 hari dibandingkan hasilnya dengan menggunakan indeks gingiva Loe and Silness. Hasil penelitian menunjukkan bahwa berkumur dengan ekstrak delima konsentrasi $10 \%$ menyebabkan penurunan skor gingiva sebesar 48\% pada minggu pertama dan $77 \%$ pada minggu ke-2 sedangkan penurunan skor gingiva dengan ekstrak delima konsentrasi $5 \%$, sebesar $11 \%$ pada minggu pertama dan $27 \%$ pada minggu ke-2. Sebagai kesimpulan, peningkatan konsentrasi ekstrak obat kumur buah delima lebih efektif menurunkan tingkat keparahan gingivitis.
\end{abstract}

Kata kunci: obat kumur, ekstrak delima, gingivitis

\section{PENDAHULUAN}

Gingivitis merupakan salah satu penyakit yang terjadi pada lebih dari $90 \%$ populasi, tanpa memperhatikan umur dan jenis kelamin. Hubungan sebab dan akibat antara plak dan inflamasi gingiva ditunjukkan oleh penelitian Loe, dkk. Plak pada bak-teri merupakan penyebab utama gingivitis, karena itu faktor yang dapat mempengaruhi kebersihan mu-lut individu dapat mempengaruhi prevalensi gingivitis. ${ }^{1}$ Gingivitis merupakan penyakit yang bersifat reversibel, yakni dapat disembuhkan dengan menghilangkan plak mikrobial dan melakukan pengendalian plak yang efektif. ${ }^{2}$ Pengendalian plak supragingival yang dilakukan dengan rutin dan secara efektif dengan menggunakan sikat gigi dan benang gigi dibutuhkan 
untuk mencegah perkembangan gingivitis menjadi periodontitis. Meskipun metode pengendalian plak secara mekanik dapat menjaga kebersihan mulut dengan baik, penelitian membuktikan bahwa metode tersebut tidak cukup akurat. Terdapat beberapa agen terapeutik yang dapat digunakan untuk mengendalikan plak bakteri, namun agen-agen ini umumnya memiliki efek samping.

Beberapa produk herbal telah dites dengan hasil yang efektif, salah satunya adalah buah delima. ${ }^{3}$ Buah delima (Punica granatum L.) merupakan buah yang dikonsumsi secara luas sebagai buah ataupun jus. Penggunaan delima dari waktu ke waktu dilaporkan memiliki kualitas terapeutik yang baik. Studi in vitro dan in vivo menunjukkan bahwa buah delima memiliki efek antioksidan, antidiabetik, hipolipidemik, antibakterial, antiinflamasi, antivirus, dan antikarsinogenik. Buah delima juga terbukti dapat meningkatkan kesehatan jantung dan rongga mulut. Manfaat buah ini didapat dari senyawa fitokimia, yang didominasi oleh golongan flavonoid dan telah terbukti memiliki aktivitas antioksidan, antiflamasi, antibakteri, dan menghilangkan plak dari permukaan gigi. Flavonoid terbesar yang terkandung dalam daging buah delima adalah antosianin. Pigmen antosianin ini memberikan karakteristik warna merah pada buah delima. ${ }^{5}$ Asam punicid yang terdapat pada biji buah delima dapat menurunkan regulasi aktivasi neutrofil dan peroksidasi lipid, karena itu buah delima ini bertindak sebagai antiinflamasi. ${ }^{6}$ Penelitian secara in vitro yang dilakukan di Brazil menyatakan bahwa efek antibakteri yang terdapat pada gel ekstrak kulit buah delima dapat melawan bakteri Streptococcus sanguis, Streptococcus mitis, dan Streptococcus mutans. $^{7}$

Menurut Ahuja, kandungan ekstrak delima 5-6\% memiliki efek antigingivitis yang lebih baik daripada klorheksidin 0,2\%, namun tidak lebih baik dalam menyingkirkan plak dibandingkan klorheksidin. ${ }^{9}$ Pada penelitian lain, ekstrak buah delima $10 \%$ dalam bentuk gel tidak efisien dalam mencegah pembentukan plak gigi dan gingivitis ${ }^{3}$, sedangkan dalam bentuk obat kumur lebih efisien jika digunakan dua kali sehari selama 15 hari dalam me-nurunkan nilai probing pada gingiva dan pendarahan gingiva jika dibandingkan klorheksidin. ${ }^{3}$

Penelitian ini bertujuan untuk mengetahui efektivitas obat kumur ekstrak buah delima yang ditingkatkan konsentrasinya dalam menurunkan indeks gingiva oleh senyawa polifenol. Buah delima dapat dibagi menjadi beberapa bagian yaitu kulit, biji, dan daging biji. ${ }^{4}$ Polifenol flavonoid yang terdapat pada ekstrak buah delima dapat mencegah gingivitis dengan cara menurunkan tekanan oksidatif pada rongga mulut.

\section{BAHAN DAN METODE}

Penelitan ini merupakan penelitian eksperimental semu dengan metode single blind dan desain pre and post study. Populasi penelitian ini adalah karyawan dan karyawati di FKG Unpad, dengan jumlah sampel sebanyak 30 orang yang dipilih secara purposive sampling kemudian dibagi menjadi 2 kelompok yaitu kelompok A, yang berkumur dengan ekstrak buah delima 5\% dan kelompok B, yang berkumur dengan ekstrak buah delima 10\%. Pemilihan subyek sesuai kriteria inklusi: laki-laki dan perempuan berusia 1825 tahun, gingivitis marginalis generalisata dengan Indeks Gingiva 1,1-2,0 (moderate) dan bersedia menjadi subyek penelitian.

Kelompok A diminta untuk berkumur menggunakan ekstrak buah delima 5\% sebanyak 10 ml sedangkan kelompok B diminta untuk berkumur menggunakan ekstrak buah delima 10\% sebanyak $10 \mathrm{ml}$. Berkumur dilakukan selama 30 detik dengan menggerakgerakan otot-otot pipi dan otot sekitar mulut secara maksimal. Berkumur dilakukan sebanyak 2 kali sehari yaitu, pagi hari setelah menyikat gigi dan malam hari setelah menyikat gigi selama 15 hari.

Indeks gingiva yang digunakan adalah indeks gingiva Loe and Silness dengan modifikasi Ramfjord. Gigi yang diperiksa berdasarkan Ramfjord adalah 16, 21, 24, 36, 43, 44. Permukaan yang diamati adalah fasial, mesial, distal dan lingual.

Hipotesis penelitian ini adalah sebagai berikut:

1. $\mathrm{H}_{0}$ : tidak ada perbedaan efektivitas obat kumur ekstrak buah delima selama satu minggu dan dua minggu.

2. $\mathrm{H}_{0}$ : tidak ada perbedaan efektivitas obat kumur ekstrak buah delima pada konsentrasi $5 \%$ dan $10 \%$.

Untuk menguji hipotesis, data hasil penelitian akan diolah menggunakan software SPSS. Penilaian indeks gingiva dilakukan sebelum dan sesudah perlakuan kepada semua subjek penelitian pada hari kedelapan dan kelima belas. Untuk melihat ada tidaknya hubungan antar variabel, dilakukan analisis menggunakan Uji korelasi Pearson.

\section{HASIL}

Pada Tabel 1 terlihat konsentrasi ekstrak buah delima terhadap efek W1 diperoleh $r=0,771$ dan $p<$ $0,01, \mathrm{H}_{0}$ ditolak dan $\mathrm{H}_{1}$ diterima. artinya terdapat hubungan yang positif dan signifikan antara konsentrasi ekstrak buah delima terhadap efek pada minggu pertama. Makin tinggi konsentrasi ekstrak, semakin tinggi efek penurunan indeks gingiva. Hal ini dikuatkan oleh data efek konsentrasi pada minggu kedua, diperoleh nilai r yang lebih tinggi, yaitu $=0,945$ 
dan $\mathrm{p}<0,01$, artinya $\mathrm{H}_{0}$ ditolak dan $\mathrm{H}_{1}$ diterima. Artinya bahwa terdapat hubungan yang positif dan signifikan antara konsentrasi ekstrak buah delima terhadap efek penurunan yang terjadi pada minggu kedua.

\section{Perbandingan Efektivitas Konsentrasi Ekstrak Buah Delima 5\% dan 10\% Terhadap Indeks Gingiva}

Nilai konversi data indeks pengaruh konsentrasi ekstrak buah delima terhadap efek penurunan indeks gingiva periode terapi antara satu minggu dan dua minggu dapat dilihat pada Tabel 2, namun secara ringkas disajikan dalam Gambar 1. Independent Sample $t$ Test digunakan untuk membandingkan perbedaan efektivitas ekstrak buah delima dilihat dari: 1) Periode terapi: satu minggu dan dua minggu; dan 2) Konsentrasi ekstrak: $5 \%$ dan $10 \%$.

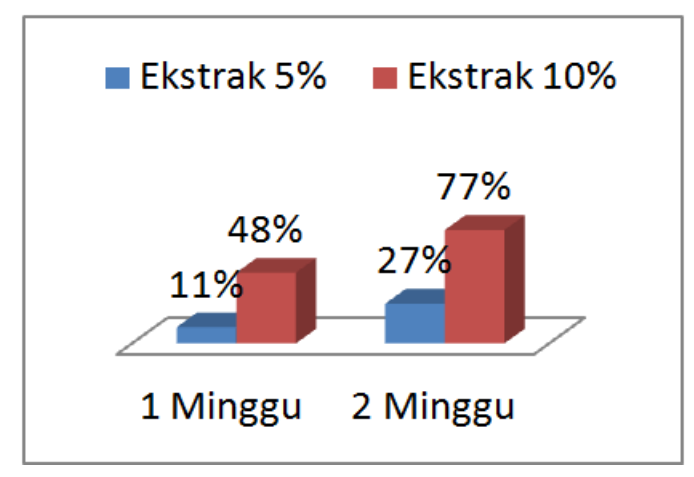

Gambar 1. Perbandingan efektivitas obat kumur ekstrak buah delima pada pemakaian selama satu minggu dan dua minggu
Tabel 1. Korelasi Pearson antara konsentrasi vs efek penurunan indeks gingiva

\begin{tabular}{|c|c|c|c|c|}
\hline \multicolumn{5}{|c|}{ Korelasi } \\
\hline & & Kons_ekstrak & Efek W1 & Efek W2 \\
\hline \multirow[t]{3}{*}{ Kons_ekstrak } & Korelasi Pearson & 1 &, $771 * *$ & , $945 * *$ \\
\hline & Sig. (2 arah) & & ,000 & ,000 \\
\hline & $\mathrm{N}$ & 30 & 30 & 30 \\
\hline \multirow{3}{*}{ Progres W1 } & Korelasi Pearson &, 771 **** & 1 &, $896 * *$ \\
\hline & Sig. (2 arah) & ,000 & & ,000 \\
\hline & $\mathrm{N}$ & 30 & 30 & 30 \\
\hline \multirow{3}{*}{ Progres W2 } & Korelasi Pearson &, $945 * * *$ &, $896 * * *$ & 1 \\
\hline & Sig. (2 arah) & ,000 & ,000 & \\
\hline & $\mathrm{N}$ & 30 & 30 & 30 \\
\hline
\end{tabular}

$\mathrm{W} 1$ = penggunaan selama minggu ke 1

$\mathrm{W} 2$ = penggunaan selama minggu ke 2

Tabel 2 menunjukkan pada minggu pertama diperoleh nilai $\mathrm{F}=18,803$ dan sig $\mathrm{p}<0,05$ (diasumsikan varians sama) dan nilai $t=-6,408$ dan $p<0,01$ yang berarti $\mathrm{H}_{0}$ ditolak dan $\mathrm{H}_{1}$ diterima, sehingga dapat disimpulkan bahwa terdapat perbedaan yang signifikan pada kedua macam perlakuan. Rata-rata indeks pada minggu pertama pada penggunaan obat kumur Ekstrak delima 5\% = 0,1975 sedangkan rata-rata indeks pada minggu pertama pada penggunaan obat Kumur Ekstrak Delima 10\%= 0,7827. Pada minggu kedua diperoleh $\mathrm{F}=18,325$ dan sig $\mathrm{p}<0,05$ (diasumsikan varians sama) diperoleh nilai $\mathrm{t}=-15,216$ dan $\mathrm{p}<0,01$ yang berarti $\mathrm{H}_{0}$ ditolak dan $\mathrm{H}_{1}$ diterima, sehingga dapat disimpulkan bahwa terdapat perbedaan yang signifikan pada kedua macam perlakuan. Rata-rata indeks pada minggu pertama pada penggunaan obat kumur ekstrak delima 5\% $=0,4625$ sedangkan rata-rata indeks pada minggu pertama penggunaan obat kumur ekstrak delima 10\%= 1,2253 .

Tabel 2. Hasil analisis independent sample T test perbedaan efektivitas periode terapi vs konsentrasi ekstrak

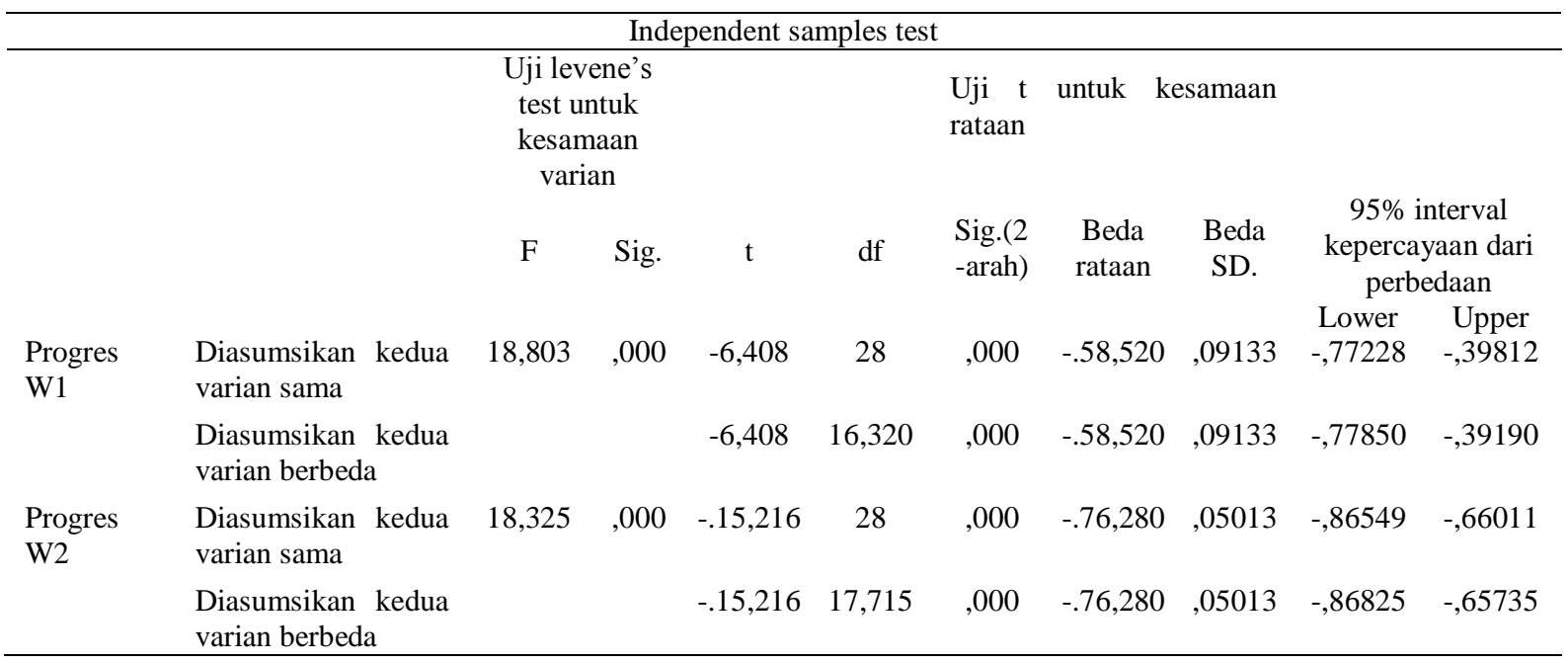




\section{Pengaruh Konsentrasi $\left(X_{1}\right)$ dan Periode Terapi $\left(X_{2}\right)$ Terhadap Efek Penurunan Indeks Gingiva (Y)}

Pada Tabel 3 tampak nilai $\mathrm{R}=0,901$ dan koefisien determinasi $R^{2}=0,811$. Hal ini menunjukkan indeks determinasi, yaitu persentase yang menyumbangkan pengaruh $\mathrm{X}_{1}$ dan $\mathrm{X}_{2}$ terhadap $\mathrm{Y}$. R2 $=0,811$ mengandung pengertian bahwa $81,1 \%$ sumbangan $X_{1}$ dan $\mathrm{X}_{2}$ terhadap $\mathrm{Y}$, sementara sisanya sebesar 18,9\% dipengaruhi oleh faktor lain. Hasil analisis ANOVA pada Tabel 3. menunjukkan bahwa nilai $\mathrm{F}=122,366$ dengan tingkat signifikansi 0,000 yang berarti bahwa terdapat pengaruh variabel $\mathrm{X}_{1}$ dan $\mathrm{X}_{2}$ terhadap $\mathrm{Y}$.

Tabel3. Hasil analisis regresi pengaruh konsentrasi $\left(\mathrm{X}_{1}\right)$ dan periode terapi $\left(\mathrm{X}_{2}\right)$ terhadap efek penurunan indeks gingiva $(\mathrm{Y})$

\begin{tabular}{ccccc}
\hline $\mathrm{N}$ & $\mathrm{R}$ & $\mathrm{R}^{2}$ & $\mathrm{~F}$ & $\mathrm{Sig}$ \\
\hline 15 &, $901^{\mathrm{a}}$ &, 811 & 122,366 &, $000^{\mathrm{a}}$ \\
a. & Prediktor: (konstan), periode, kons ekstrak & \\
b. & Variabel terikat : Efektivitas & \\
\hline
\end{tabular}

Tabel 4. Hasil uji Anova pengaruh variabel $\mathrm{X}_{1}$ dan $\mathrm{X}_{2}$ terhadap Y

\begin{tabular}{|c|c|c|c|c|c|c|}
\hline \multicolumn{7}{|c|}{ Koefisien $^{\mathrm{a}}$} \\
\hline \multirow[t]{2}{*}{ Model } & & \multicolumn{2}{|c|}{$\begin{array}{l}\text { Koefisien tidak } \\
\text { terstandar }\end{array}$} & $\begin{array}{l}\text { Koefisien } \\
\text { terstandar }\end{array}$ & $\mathrm{T}$ & Sig. \\
\hline & & B & $\begin{array}{l}\text { Std. } \\
\text { kesalahan }\end{array}$ & Beta & & \\
\hline \multirow[t]{3}{*}{1} & (Konstan) & $-56,497$ & 6,868 & & $-8,226$ & ,000 \\
\hline & Kons Ekstrak & 43,473 & 3,151 & ,794 & 13,795 &, 000 \\
\hline & Periode & 23,251 & 3,151 & 425 & 7,378 &, 000 \\
\hline \multicolumn{7}{|c|}{ a.Variabel terikat: Efektivitas } \\
\hline
\end{tabular}

Analisis Anova menunjukkan bahwa untuk variabel $\mathrm{X}_{1}$ (konsentrasi), diperoleh nilai koefisien a dan $b$ serta harga $t$ hitung dan tingkat signifikansi sehingga menghasilkan persamaan:

$\mathrm{y}=43,473 X_{1}-56,497$.

dimana: $\mathrm{Y}=$ Efektivitas penurunan indeks gingiva; $\mathrm{X}_{1}=$ Konsentrasi Ekstrak

artinya jika tidak ada kenaikan konsentrasi ekstrak, maka penurunan indeks gingiva pasien adalah sebesar $56,5 \%$. Sedangkan setiap ada penambahan $1 \%$ konsentrasi ekstrak, maka akan ada peningkatan efek sebesar $43,473 \%$; selanjutnya untuk variabel $\mathrm{X}_{2}$ (periode terapi), diperoleh nilai koefisien a dan $\mathrm{b}$ serta harga $t$ hitung dan tingkat signifikansi sehingga menghasilkan persamaan:

$\mathrm{y}=23,251 \mathrm{X}_{2}-56,497$.

dimana: Y=Efektivitas penurunan indeks gingiva; $\mathrm{X}_{1}=$ Periode terapi artinya Jika tidak ada peningkatan periode, maka penurunan indeks gingiva pasien adalah sebesar $56,5 \%$. Sedangkan setiap ada penambahan satu minggu periode terapi, maka akan ada peningkatan efek sebesar $23,251 \%$. Tabel 4 juga menunjukkan bahwa nilai $\mathrm{t}=13,795$ dan sig $(\mathrm{p})=$ 0,000 , yang mana $\mathrm{p}<0,01$ sehingga $\mathrm{H}_{0}$ ditolak dan $\mathrm{H}_{1}$ diterima. Jadi terdapat pengaruh yang signifikan dari konsentrasi ekstrak buah delima terhadap efek penurunan indeks gingiva; dan nilai $\mathrm{t}=7,378$ dan sig $(p)=0,000$, dimana $\mathrm{p}<0,01$ sehingga $\mathrm{H}_{0}$ ditolak dan $\mathrm{H}_{1}$ diterima. Jadi terdapat pengaruh yang signifikan dari lamanya periode terapi terhadap efek penurunan indeks gingiva. Berdasarkan analisis regresi, karena nilai Beta $X_{1}$ (Konsentrasi Ektrak)= 0,794 lebih besar dari nilai Beta $X_{2}$ (periode terapi) yaitu 0,425 , maka dapat disimpulkan bahwa variabel konsentrasi ekstrak buah delima lebih berpengaruh terhadap efek penurunan indeks gingiva subyek dibandingkan lamanya periode terapi.

\section{PEMBAHASAN}

Hasil analisis korelasi Pearson menunjukkan bahwa antara variabel konsentrasi terdapat hubungan yang positif dan signifikan antara konsentrasi ekstrak buah delima terhadap efek penurunan indeks gingiva. Hal ini dibuktikan melalui hasil penelitian yang menunjukkan bahwa konsentrasi ekstrak buah delima 5\% dan 10\% sama-sama memiliki kemampuan terhadap penurunan indeks gingiva.

Pada minggu pertama, terdapat penurunan indeks gingiva setelah berkumur kedua macam ekstrak. Hasil penelitian menunjukkan bahwa kemampuan menurunkan indeks gingiva tampak lebih tinggi pada ekstrak buah delima dengan konsentrasi $10 \%$ dibandingkan dengan konsentrasi 5\%. Pemeriksaan pada minggu ke dua, tampak penurunan yang cukup nyata dari kedua ekstrak dalam menurunkan indeks gingiva. Namun penurunan indeks gingiva paling tinggi diberikan oleh ekstrak buah delima dengan konsentrasi $10 \%$.

Pada Gambar 1, terlihat bahwa pada pemeriksaan indeks gingiva minggu pertama, ekstrak buah delima $10 \%$ lebih banyak menurunkan indeks gingiva dibandingkan dengan ekstrak buah delima 5\%, dan pada minggu ke dua, efek ekstrak delima 5\% masih lebih rendah dibandingkan efek ekstrak buah delima $10 \%$ pada minggu pertama. Hal ini dapat dikatakan bahwa dengan berkumur ekstrak buah delima $10 \%$ selama 1 minggu masih lebih baik efeknya daripada berkumur ekstrak buah delima 5\% selama dua minggu. Pengaruh konsentrasi menunjukkan kepekatan dan jumlah zat terlarut yang terdapat dalam obat kumur. Semakin tinggi konsentrasi berarti semakin banyak jumlah bahan aktif yang terkandung di dalamnya, sehingga semakin besar pula kekuatan sediaan yang dapat berpengaruh, khususnya terhadap bakteri plak.

Penurunan indeks gingiva pada kedua kondisi ini 
menunjukkan bahwa kandungan dalam ekstrak buah delima sangat baik dalam mengurangi peradangan pada gusi. Hasil ini sesuai dengan penelitian Narayan, et al..$^{5}$ bahwa kandungan bahan aktif buah delima dapat memberikan aktivitas antioksidan, anti-inflamasi, antibakteri dan antiplak. Kemampuan kandungan bahan aktif yang terdapat dalam buah delima tersebut terbukti dapat menurunkan tingkat peradangan pada gusi.

Perubahan signifikan dalam penurunan indeks gingiva terjadi dengan bertambahnya konsentrasi ekstrak. Ekstrak buah delima 10\% menyebabkan penurunan indeks gingiva sebesar $48 \%$, sedangkan larutan ekstrak buah delima 5\% hanya menurunkan indeks gingiva sebesar $11 \%$ pada minggu pertama. Demikian pula pada minggu kedua, larutan ekstrak $10 \%$ menurunkan indeks gingiva hingga $77 \%$ sementara larutan ekstrak 5\% hanya menurunkan indeks gingiva sebesar $27 \%$. Hasil analisis regresi linier menunjukkan bahwa kedua variabel sama-sama memberikan pengaruh terhadap penurunan indeks gingiva dimana pada minggu kedua terapi tampak perubahan yang lebih baik dibandingkan perubahan yang terjadi dalam minggu pertama.

Berdasarkan analisis regresi juga dapat diketahui bahwa variabel konsentrasi ekstrak memiliki pengaruh lebih dominan terhadap efek penurunan indeks gingiva subyek dibandingkan dengan lamanya periode terapi. Hal ini dapat menjadi dasar pertimbangan dalam menentukan regimen terapi yang akan diterapkan kepada pasien, bahwa untuk memperoleh penurunan indeks gingiva dalam waktu yang tidak terlalu lama, maka perlakuan yang dapat diberikan adalah dengan cara meningkatkan konsentrasi ekstrak buah delima yang digunakan.

Penurunan indeks gingiva pada penelitian ini berkaitan dengan pengurangan akumulasi plak akibat aktivitas ekstrak buah delima. Plak merupakan etiologi utama terjadinya peradangan gusi. Bakteri yang terkandung dalam plak dapat terus berkembang biak dan semakin mengiritasi gusi apabila tidak dilakukan upaya pengendalian plak. Peranan bakteri plak ini dapat dipengaruhi oleh kandungan dalam ekstrak buah delima yaitu tannin, saponin, polifenol, flavo-

\section{DAFTAR PUSTAKA}

1. Carranza F, Newman MG, Takei. Clinical Periodontology $10^{\text {th }}$ edition. Philladelphia: Saunders Elsevier, 2006: 156

2. Lindhe J, Karring T, Lang NP. Clinical Periodontology and Implant Dentistry $5^{\text {th }}$ ed., UK; Blackwell Munksgard, 2008: 185-6.

3. Prasad D, Kunnaiah R. Punica granatum: a review on its potential role in treating periodontal disease., Jisponline, 2015: 428-32. noid dan triperten yang dapat menghambat pertumbuhan Streptococcus mutans, Streptococcus mitis dan Candida albican. ${ }^{9}$ Namun, hasil penelitian ini bertentangan dengan penelitian yang dilakukan oleh Salgado, et al..$^{10}$ tahun 2006 yang menyatakan bahwa aplikasi gel yang mengandung ekstrak buah delima $10 \%$ tidak dapat mengurangi gingivitis dan pembentukan plak supragingival. Hasil penurunan indeks gingiva setelah berkumur dengan ekstrak buah delima 5\% dan $10 \%$ tidak akan menyebabkan gusi menjadi sembuh dari peradangan, sebab selama permukaan gigi masih terdapat plak yang terakumulasi dan sudah matang, maka pengaruh aktivitas kandungan ekstrak buah delima hanya dapat mengurangi tingkat keparahannya saja.

Tindakan yang utama dalam menangani peradangan gusi akibat plak adalah dengan cara mekanis seperti penyikatan gigi. Obat kumur ekstrak buah delima dapat digunakan sebagai pelengkap setelah tindakan penyikatan gigi. Pada penelitian ini, subyek yang telah mengikuti prosedur penelitian merasakan rasa larutan kumur ekstrak buah delima yang pahit dan kurang enak pada saat pertama kali berkumur. Namun seiring dengan dibiasakannya berkumur sesuai prosedur penelitian, para subyek mulai terbiasa dan bahkan merasakan manfaat lain seperti rongga mulut terasa lebih sehat dan segar, bahkan tidak ditemukan adanya laporan subyek yang mengalami efek samping yang buruk. Dari hasil penelitian ini dapat disimpulkan bahwa peningkatan konsentrasi ekstrak dari obat kumur buah delima dapat menurunkan tingkat keparahan gingivitis secara lebih efektif.

\section{UCAPAN TERIMA KASIH}

Terima kasih kepada Fakultas Kedokteran Gigi Universitas Padjadjaran yang telah memfasilitasi penelitian ini untuk dibiayai oleh Universitas Padjadjaran. Sekolah Ilmu dan Teknologi Hayati Institut Teknologi Bandung yang telah membantu dalam determinasi tumbuhan.

4. Alvares P, Lopez J, Martos M. Pomegranate and its many functional components as related to human health. Comprehensive Review in Food Science and Food Safety 2010., 9: 653-4.

5. Narayan T, Deshpande S, Jha A, Ramprasad VP. Punica granatum (Pomegranate) fruit and its relevance in oral hygiene. IOSR J Dental and Medical Sciences, 2014; 13(8): 29-34. 
6. Karkare RS, Shamim SF. Role of Pomegranate In Preventive Dentistry. International Journal of Research in Ayurveda \& Pharmacy 2012; 3(5): 64849

7. Howe AB, D'Souza DH. The pomegranate: effect on bacteria andviruses that influence human health. Hindawi Publishing Corporation, 2013: 1-11.

8. Ahuja SA. Comparative evaluation of efficacy of punica granatum and chlorhexidine on plaque and gingivitis. Journal of the International Clinical Dental Research Organization 2011, 3: 29.

9. Smullen J, Finney M, Storey DM, Foster HA. Prevention of artificial dental plaque formation in vitro by plant extracts. Journal of Applied Microbiology 2012; 113(4): 964-73.

10. Salgado. Antiplaque and antigingivitis effect of a gel containing punica granatum linn exctract. A doubleblind clinical study humans. Brazil. J Appl Oral Sci 2006; 14 (3): 162-6 